\title{
Does the Tagus estuary fish community reflect environmental changes?
}

\author{
H. N. Cabral*, M. J. Costa, J. P. Salgado \\ Instituto de Oceanografia, Faculdade de Ciências da Universidade de Lisboa, R. Ernesto Vasconcelos, \\ Lisboa 1749-016, Portugal
}

\begin{abstract}
Estuarine fish communities are usually used in an ecological monitoring context to infer the environmental changes ocurring in estuarine environments. In the present paper several analytical tools, namely community analysis indices, species-ranking methods and multivariate ordination techniques, were applied to time series data for the Tagus fish community for 2 periods: 1979 to 1981 and 1995 to 1997 . Assessment of the relative importance of anthropogenic versus naturally induced fluctuations is made difficult by the range of natural short-term variations. For the Tagus case study, multivariate ordination techniques, rather than the ranking methods and indices analyzed, provide a good indicator of long-term changes. The major trends in the changes observed in this fish community were a decrease in abundance for several species that use the estuary as a nursery area and an increase in some resident species, namely Gobius spp. and Halobatrachus didactylus. Several species with southern European affinities have increased their importance within the Tagus estuarine fish community.
\end{abstract}

KEY WORDS: Fish community - Environmental changes · Assessment methods · Tagus estuary · Portugal Resale or republication not permitted without written consent of the publisher

\section{INTRODUCTION}

Human activities have a considerable impact on estuarine fish communities. Agricultural, industrial and engineering projects alter the shape and nature of estuaries, domestic and industrial discharges add pollution stress and heavy fishing pressure has a significant effect on abundance and community structure (Haedrich 1983).

Several levels of biological organization have been used to investigate the health of an estuarine system and to assess environmental impacts (Attrill \& Depledge 1997), but the community level has been suggested as being the most important for impact studies (e.g. Clements \& Kiffney 1994, Paller et al. 1996).

Several authors (e.g. Elliott et al. 1988, Warwick 1993) have outlined a set of advantages of using fish communities in environmental impact studies, namely

*E-mail: hcabral@fc.ul.pt the high mobility of fish species, the speed of processing samples and the fact that they allow a multi-trophic approach. Despite these advantages, there are some features that reduce their usefulness, such as the difficulty of achieving effective quantitative sampling, the conflict of mobility versus fidelity and, especially, the slow response time to disturbance. However, it should be emphasized that the majority of these negative aspects would also apply to other taxonomic groups (e.g. invertebrates) that may be used in biological monitoring (Whitefield 1996).

The Tagus estuary has long been subjected to industrial development, urbanization and port and fishing activities. Costa \& Elliott (1991), Fernandes et al. (1995) and Costa \& Cabral (1999) emphasized the most important human pressures and conflicts due to these multiple uses and their significance for nature conservation.

The fish community of the Tagus estuary has been studied since the late 1970 s. In the first studies, con- 
ducted from 1978 to 1981, Costa (1986) recorded $\sim 40$ species. Costa \& Bruxelas (1989) identified 7 species that use this estuary as a nursery: Trisopterus luscus (Linnaeus, 1758), Ciliata mustela (Linnaeus, 1758), Dicentrarchus labrax (Linnaeus, 1758), Trigla lucerna Linnaues, 1758, Platichthys flesus (Linnaeus, 1758), Solea solea (Linnaeus, 1758) and Solea senegalensis Kaup, 1858. After these first studies, only occasional surveys were performed until 1994 (in 1986 and 1988). Since 1994, an effort has been made to continue this time

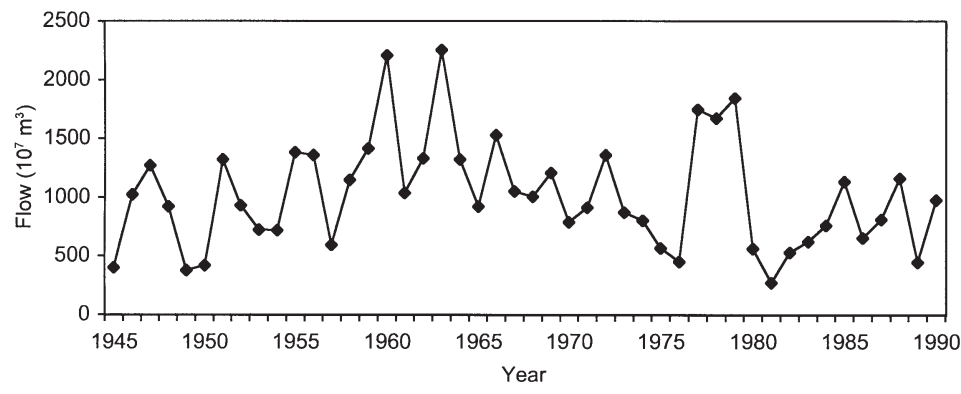
series and more detailed studies have been undertaken. These later studies showed that some fish species were present in very low numbers or were even absent (Costa \& Cabral 1999).

Although the fish abundance and environmental data available are limited, the present paper aims to evaluate several analytical techniques in order to relate the fish community with the environmental changes in the system.

\section{MATERIAL AND METHODS}

2.1. Study area. The Tagus estuary (Fig. 1), with an area of $320 \mathrm{~km}^{2}$, is a mesotidal estuary with a tidal

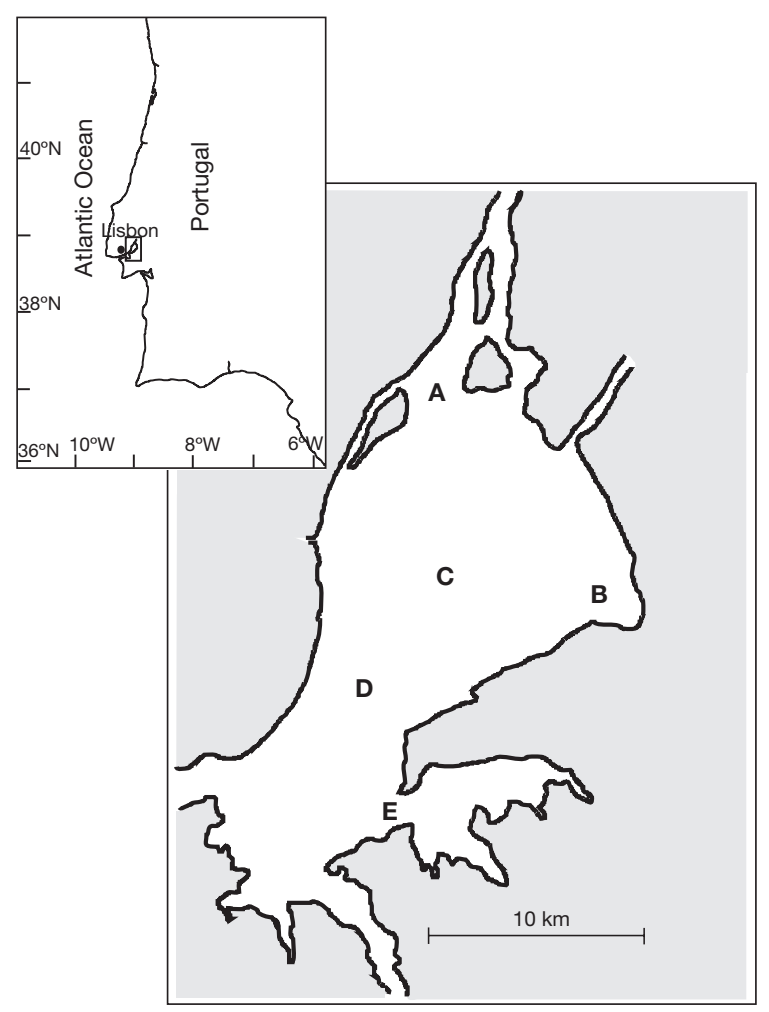

Fig. 1. Sampling areas within the Tagus estuary

Fig. 2. Annual mean flow of Tagus river from 1945 to 1990

amplitude of $\sim 4 \mathrm{~m}$. The intertidal and saltmarsh areas are $\sim 40 \%$ of the total estuarine area. The mean river flow is $\sim 400 \mathrm{~m}^{3} \mathrm{~s}^{-1}$, being highly variable both seasonally and interannually (Fig. 2). Salinity varies from $0 \%$, $\sim 50 \mathrm{~km}$ upstream from the mouth, to nearly $37 \%$ at the mouth of the estuary. Water temperature ranges from 8 to $26^{\circ} \mathrm{C}$.

The estuary has long been subjected to industrial development and urbanization. Several hundred industries labor along the estuarine borders. The upper part is bordered by land used intensively for agriculture (Fernandes et al. 1995). The Lisbon metropolitan area is heavily populated, with the highest increase in population to date occurring between 1970 and 1980 (Fig. 3). At present, ca 2 million people live around the estuary.

Water quality control and monitoring in the river Tagus basin is recent. Holistic overviews of pollution estimates are particularly scarce, but the values determined for discharges in the river are generally higher compared to the estuary (Table 1).

The estuary has an important role as an overwintering area and feeding ground for birds. Part of the estuarine area is a nature reserve (Tagus Estuary Nature Reserve). In addition, some areas have special protection status (Birds Directive 79/409/EEC).

2.2. Sampling surveys and data analysis. The fish community of the Tagus estuary was studied based on monthly beam trawl catches in surveys made between 1979 and 1981 (Costa 1986) and from 1995 until 1997 (Cabral 1998, Costa et al. 1998). A $4 \mathrm{~m}$ beam trawl with one tickler chain and $10 \mathrm{~mm}$ mesh size was used and towed for $15 \mathrm{~min}$ at $\sim 1$ knot. The location of sampling stations in the 2 periods was similar, covering the whole estuarine area (Fig. 1). At each sampling station the number of hauls per month varied from 2 to 4 .

To enable comparisons between the 2 periods, and because taxonomic resolution has changed over the period, some species were merged into higher taxa.

In order to assess community structure, an ecological guild (EG) was attributed to each fish species according to McHugh (1967) and Elliott \& Dewailly (1995): 


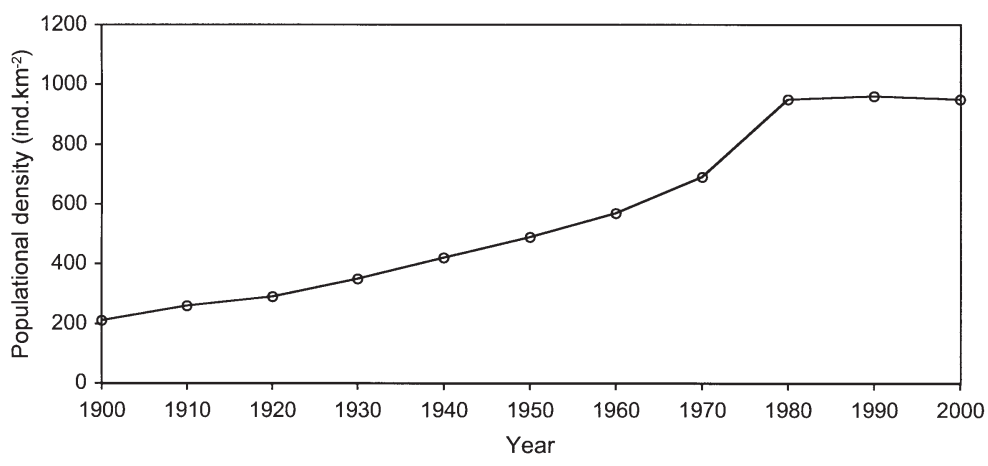

Fig. 3. Population density in the metropolitan region of Lisbon since 1900

formed using log transformed abundance data of the 20 most abundant species in the years overall. The PCA was performed using Statistica software (Statsoft 1993).

The available data on environmental conditions in the 2 periods considered was surface water temperature values in 2 estuarine sites (near Stns C and D, Fig. 1), recorded at identical tidal conditions in March and November 1980-1982 and 1995-1996, and time series values for air temperature and phosphates, nitrites and ammonia concentration in the Tagus river. Differences in water temperature values in the 2 periods were tested using a $t$-test and considering a

ER, estuarine resident species; MA, marine adventitious species; CA, diadromous species; MS, marine seasonal migrant species, that occur in the estuary both as juvenile or adult; MJ, marine migrant species, that occur in the estuary mainly as juveniles; FW, freshwater adventitious species. The chi-square statistic was used for the analysis of the contingency table of the number of species per ecological guild for each year (Zar 1996). The null hypothesis tested was that the number of species for each guild was the same in the periods considered.

To investigate species-abundance relationships, species were ranked according to their abundance in each year. A Friedman test was used to evaluate the concordance of the ranks of the 20 most abundant species (in the years overall) during the periods considered. Spearman rank correlation coefficients were calculated to examine differences between all possible pairs of years (Zar 1996). Species rank-abundance distributions were also determined for each year, based on the 20 most abundant species. Several indices were calculated, namely species richness (Margalef 1958), Shannon-Weaver (Shannon \& Weaver 1949) and evenness (Pielou 1977). Community structure was also evaluated using a principal components analysis (PCA), based on the species abundance data. This analysis was per-

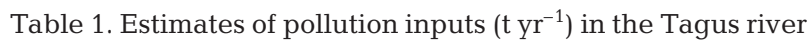
and estuary in early 1980s (according to the national environment agency)

\begin{tabular}{|lrr|}
\hline Input & \multicolumn{1}{c}{ River } & Estuary \\
\hline Suspended solids & 1000000 & 80000 \\
Total nitrogen & $>30000$ & 10000 \\
Inorganic dissolved nitrogen & 8000 & 2500 \\
Total phosphorus & $>2200$ & 1200 \\
Phosphates & 4100 & 2300 \\
Mercury & 0.24 & 5.7 \\
\hline
\end{tabular}

0.05 significance level. The variation trends of the other environmental variables, throughout the time periods considered, were evaluated by Spearman rank correlation tests. These test procedures were performed using Statistica software (Statsoft 1993).

\section{RESULTS}

Although a similar species composition was found in the periods considered (Table 2), ranks based on abundance data were significantly different (Friedman $\chi^{2}=$ $29.68, \mathrm{p}<0.05)$. The Spearman rank correlations determined for all the possible pairs of years showed that the significant differences were mainly obtained for the years of the baseline (1979-1981) relative to recent surveys (1995-1997) (Table 3).

Pomatoschistus spp. were the dominant species in all the years studied. Several other species presented similar ranks in all the periods, namely Solea spp., Engraulis encrasicolus (Linnaeus, 1758) and Dicentrarchus labrax, which were always found within the 10 most abundant species. The major differences between the baseline and recent surveys were a decrease in the abundance of Sprattus sprattus (Linnaeus, 1758), Platichthys flesus, Ciliata mustela, Trisopterus luscus and Trigla lucerna from 1979-1981 to 1995-1997, and an increase in the ranks of Liza ramada (Risso, 1826), Halobatrachus didactylus, Diplodus bellottii (Steindachner, 1885), Sparus aurata Linnaeus, 1758, and Argyrosomus regius (Asso, 1801) in the later period.

The species rank-abundance relation (Fig. 4) showed mainly 2 different patterns. In 1979, 1980 and 1997 the first of the most abundant species represented between 59 and $70 \%$ of the total number of individuals of all the species, while in the other years the values ranged from 75 to $95 \%$. Other differences between the 2 groups of species-abundance distributions were due to the relative contributions of the 10 
most abundant species, which was more equable in 1979, 1980 and 1997 in comparison with the other periods.

The fish community structure based on ecological guilds was very similar in all the years considered (Table 4). The most representative ecological guilds were marine migrant species, which occur in the estuary mainly as juveniles, marine adventitious species and estuarine resident species. The highest variation in the number of species per guild was noticed for the marine adventitious species, which varied from 4 to 13 species. The differences in the number of species per

Table 2. Species mean density $\left(1000 \mathrm{~m}^{-2}\right)$ and rank according to abundance data (in parentheses and in decreasing order) for the periods studied (1979-1981 and 1995-1997) and ecological guild (EG)

\begin{tabular}{|c|c|c|c|c|c|c|c|}
\hline Species & EG & 1979 & 1980 & 1981 & 1995 & 1996 & 1997 \\
\hline Mustelus mustelus & MA & - & - & - & $<0.01(34.5)$ & - & - \\
\hline Raja clavata & MA & - & - & - & - & $<0.01(27.5)$ & $<0.01(29.5)$ \\
\hline Raja undulata & MA & $<0.01(22.5)$ & - & - & $<0.01(28.5)$ & $0.01(21)$ & $0.03(17)$ \\
\hline Sardina pilchardus & MJ & - & $0.08(15)$ & $1.23(4)$ & $0.06(14)$ & $0.02(16.5)$ & $0.03(18)$ \\
\hline Sprattus sprattus & MA & $0.42(8)$ & $0.02(22)$ & $<0.01(21.5)$ & - & - & - \\
\hline Engraulis encrasicolus & ER & $1.92(2)$ & $3.72(4)$ & $0.17(7)$ & $0.52(4)$ & $0.27(7)$ & $0.67(7)$ \\
\hline Anguilla anguilla & $\mathrm{CA}$ & $1.29(3)$ & $3.68(5)$ & $0.07(10)$ & $0.09(8)$ & $0.24(8)$ & $0.06(15)$ \\
\hline Conger conger & MA & - & $0.06(19.5)$ & $<0.01(21.5)$ & $0.01(16)$ & $0.01(20)$ & $0.05(16)$ \\
\hline Hippocampus hippocampus & ER & $0.01(22.5)$ & $0.01(26.5)$ & - & - & $0.01(24.5)$ & $0.15(11)$ \\
\hline Syngnathus acus & ER & - & - & - & $<0.01(34.5)$ & - & - \\
\hline Syngnathus thyphle & ER & $0.01(22.5)$ & - & $0.05(12)$ & $<0.01(25)$ & $<0.01(31.5)$ & - \\
\hline Syngnathus sp. & ER & $0.56(7)$ & $11.19(3)$ & $19.32(2)$ & $0.06(13)$ & $0.22(9)$ & $0.87(4)$ \\
\hline Trisopterus luscus & MJ & $0.14(13.5)$ & $0.17(13)$ & $0.02(13)$ & - & - & - \\
\hline Ciliata mustela & MJ & $0.14(13.5)$ & $1.88(6)$ & $<0.01(15.5)$ & 0122.5 & - & - \\
\hline Serranus cabrilla & MA & - & - & - & $<0.01(34.5)$ & - & - \\
\hline Serranus hepatus & MA & - & - & - & - & - & $<0.01(29.5)$ \\
\hline Dicentrarchus labrax & $\mathrm{MJ}$ & $0.97(5)$ & $1.68(7)$ & $0.19(6)$ & $0.08(10)$ & $1.85(2)$ & $0.56(9)$ \\
\hline Trachurus trachurus & MA & $0.01(22.5)$ & $0.02(23.5)$ & $<0.01(21.5)$ & $<0.01(34.5)$ & $0.01(24.5)$ & - \\
\hline Argyrosomus regius & $\mathrm{MJ}$ & - & - & - & $0.11(7)$ & $0.03(22)$ & $0.15(12)$ \\
\hline Mullus surmuletus & MA & - & - & - & $<0.01(28.5)$ & - & - \\
\hline Diplodus annularis & MA & - & - & - & $<0.01(28.5)$ & - & - \\
\hline Diplodus bellottii & $\mathrm{MJ}$ & - & - & - & $0.01(17)$ & $0.03(14)$ & $0.64(8)$ \\
\hline Diplodus sargus & MJ & - & - & - & - & $0.02(19)$ & $0.02(19)$ \\
\hline Diplodus vulgaris & MJ & $0.01(22.5)$ & $0.12(14)$ & $<0.01(21.5)$ & $0.03(15)$ & $0.13(11)$ & $0.02(20.5)$ \\
\hline Sarpa salpa & MA & $0.01(22.5)$ & - & - & - & - & - \\
\hline Sparus aurata & $\mathrm{MJ}$ & - & - & - & $0.07(12)$ & $0.02(16.5)$ & $0.06(14)$ \\
\hline Spondyliosoma cantharus & MA & - & $0.01(26.5)$ & - & $<0.01(34.5)$ & - & - \\
\hline Symphodus bailloni & $\mathrm{ER}$ & - & - & - & $0.01(20)$ & $<0.01(27.5)$ & $0.01(26.5)$ \\
\hline Aphia minuta & MA & - & $0.04(21)$ & $<0.01(21.5)$ & $<0.01(25)$ & $0.01(24.5)$ & $0.01(26.5)$ \\
\hline Gobius sp. & ER & $0.10(15)$ & $0.20(12)$ & $0.01(14)$ & $0.15(5)$ & $0.45(5)$ & $0.85(5)$ \\
\hline Pomatoschistus sp. & ER & $16.16(1)$ & $57.30(1)$ & $84.31(1)$ & $43.95(1)$ & $149.12(1)$ & $20.02(1)$ \\
\hline Callionymus lyra & MA & - & $0.06(17)$ & $<0.01(21.5)$ & $<0.01(34.5)$ & - & - \\
\hline Callionymus maculatus & MA & - & - & - & $<0.01(34.5)$ & - & - \\
\hline Parablennius gattorugine & MA & - & $<0.01(26.5)$ & - & - & $<0.01(31.5)$ & - \\
\hline Chelon labrosus & MS & $0.01(22.5)$ & $0.06(18)$ & $<0.01(21.5)$ & $0.01(20)$ & $<0.01(31.5)$ & - \\
\hline Liza aurata & $\mathrm{MJ}$ & $0.17(12)$ & $0.70(9)$ & $0.16(9)$ & $0.09(9)$ & $0.03(15)$ & $0.01(23.5)$ \\
\hline Liza ramada & $\mathrm{CA}$ & $0.18(11)$ & $0.26(11)$ & $<0.01(21.5)$ & $0.68(3)$ & $1.42(4)$ & $1.43(3)$ \\
\hline Mugil cephalus & MS & $0.03(16)$ & $0.06(16)$ & $0.01(15.5)$ & $0.01(20)$ & $0.02(18)$ & $0.01(22)$ \\
\hline Cyprinus carpio & FW & $0.30(9)$ & $0.01(26.5)$ & - & - & - & - \\
\hline Barbus bocagei & FW & $0.02(17)$ & - & - & $0.08(1)$ & $0.32(6)$ & $0.49(10)$ \\
\hline Atherina sp. & ER & $0.77(6)$ & - & $6.75(3)$ & $0.01(22.5)$ & $0.03(12.5)$ & $0.09(13)$ \\
\hline Trigla lucerna & MJ & $0.02(18)$ & $0.61(10)$ & $0.05(11)$ & $<0.01(34.5)$ & $0.01(24.5)$ & $0.02(20.5)$ \\
\hline Scophthalmus rhombus & MA & - & $0.02(23.5)$ & - & $<0.01(28.5)$ & $<0.01(31.5)$ & - \\
\hline Arnoglossus laterna & MA & - & - & - & - & - & $<0.01(29.5)$ \\
\hline Bothus podas & MA & - & - & - & - & $<0.01(31.5)$ & - \\
\hline Platichthys flesus & $\mathrm{MJ}$ & $0.24(10)$ & $1.02(8)$ & $0.47(5)$ & $0.11(6)$ & $0.03(12.5)$ & $0.01(25)$ \\
\hline Dicologoglossa cuneata & MJ & - & $0.06(19.5)$ & $<0.01(21.5)$ & - & $<0.01(31.5)$ & $0.01(23.5)$ \\
\hline Solea spp. & $\mathrm{MJ}$ & $1.29(4)$ & $13.64(2)$ & $0.16(8)$ & $4.53(2)$ & $1.56(3)$ & $0.73(6)$ \\
\hline Balistes carolinensis & MA & - & - & - & $<0.01(25)$ & - & $<0.01(29.5)$ \\
\hline Halobatrachus didactylus & ER & - & - & - & $0.01(18)$ & $0.21(10)$ & $1.45(2)$ \\
\hline
\end{tabular}




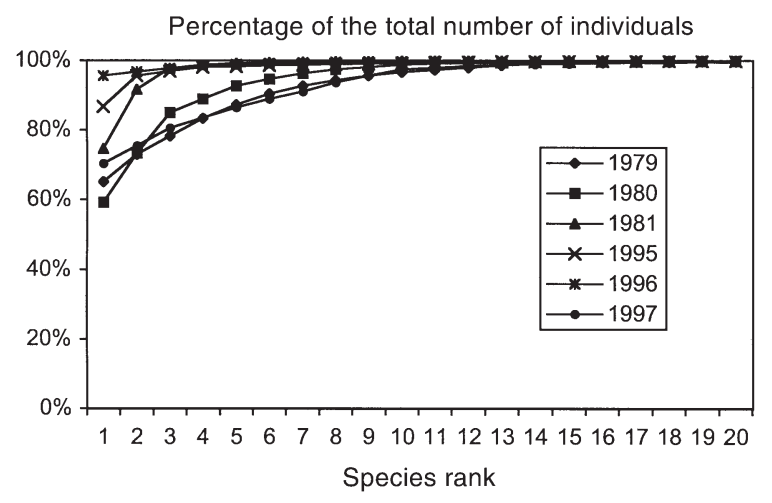

Fig. 4. Species rank-abundance distributions for the years considered

guild in the several years considered, evaluated by the $\chi^{2}$ test, were not significant $\left(\chi^{2}=8.46, p>0.05\right)$.

The range of the values of richness, ShannonWeaver and evenness indices obtained for the baseline and recent surveys were not very different. Nevertheless, it was noticed that species richness values were generally higher in recent years, while the maximum values of diversity and evenness were obtained in the baseline surveys (Table 5).

Principal components analysis of species abundance data accounted for $72 \%$ of the variance with the first 2 ordination axes (Table 6). The ordination diagram of the first 2 axes showed that the points relative to baseline survey years were found to the left of the diagram while those of recent surveys were located to the right

Table 3. Spearman rank correlations between all possible pairs of years $\left({ }^{*}\right.$ correlations significantly different from 0 , for

$$
\chi^{2} \text { test }
$$

\begin{tabular}{|llllll|}
\hline & 1979 & 1980 & 1981 & 1995 & 1996 \\
\hline 1980 & $0.81^{*}$ & & & & \\
1981 & $0.65^{*}$ & $0.56^{*}$ & & & \\
1995 & $0.54^{*}$ & $0.48^{*}$ & 0.23 & & \\
1996 & $0.64^{*}$ & 0.43 & 0.29 & $0.66^{*}$ & \\
1997 & 0.23 & 0.12 & 0.10 & 0.43 & $0.71^{*}$ \\
\hline
\end{tabular}

(Fig. 5). This pattern along the first principal component was related to an increase in the abundance of Lisa ramada, Gobius spp., Halobatrachus didactylus, Barbus bocagei (Steindachner, 1866), Diplodus bellottii, Argyrosomus regius, Diplodus vulgaris (E. G. SaintHilaire, 1817) and Sparus aurata, which presented factor loadings higher than 0.7 (Table 7). The dispersion along the second principal component was higher in the baseline survey years and was positively associated with the abundance of Solea spp., Engraulis encrasicolus, Anguilla anguilla (Linnaeus, 1758), Ciliata mustela and Liza aurata (Risso, 1810) and negatively with Atherina spp. (Table 7).

Significant differences were obtained between water temperature values in baseline (1980-1983) and recent surveys (1995-1996) (Table 8), in both the months considered $(t=-2.77, \mathrm{p}<0.05$; and $t=-3.63$, $\mathrm{p}<0.05$; for March and November respectively). Mean water temperature values in recent surveys were $1.2^{\circ} \mathrm{C}$ and $1.3^{\circ} \mathrm{C}$ higher for March and November respectively, than those determined for the same periods in the baseline surveys.

Table 5. Richness $(D)$, Shannon-Weaver $(H)$ and Evenness $(J)$ indexes values determined for each year

\begin{tabular}{|lllllll|}
\hline & 1979 & 1980 & 1981 & 1995 & 1996 & 1997 \\
\hline$D$ & 3.04 & 2.82 & 2.51 & 3.52 & 3.01 & 3.89 \\
$H$ & 1.21 & 1.39 & 0.84 & 0.60 & 0.29 & 1.28 \\
$J$ & 0.37 & 0.41 & 0.26 & 0.17 & 0.08 & 0.35 \\
\hline
\end{tabular}

Table 6. Eigenvalues and variance associated with the first 3 ordination axes of the principal components analysis performed for species abundance data

\begin{tabular}{|lccc|}
\hline Axes & 1 & 2 & 3 \\
\hline Eigenvalue & 8.36 & 6.03 & 2.18 \\
\% Total variance & 41.8 & 30.1 & 10.9 \\
\% Cumulative variance & 41.8 & 71.9 & 82.8 \\
\hline
\end{tabular}

Table 4. Number of species per ecological guild for the years considered

\begin{tabular}{|lrrrrr|}
\hline Ecological guild & 1979 & 1980 & 1981 & 1995 & 1996 \\
\hline ER (Estuarine resident) & 7 & 5 & 7 & 9 & 9 \\
MA (Marine adventitious) & 4 & 8 & 4 & 13 & 8 \\
CA (Diadromous) & 2 & 2 & 2 & 2 & 2 \\
MS (Marine seasonal migrants, both as juvenile or adult) & 2 & 2 & 2 & 2 & 2 \\
MJ (Marine migrant species, mainly as juveniles) & 8 & 10 & 10 & 11 & 12 \\
FW (Freshwater adventitious) & 2 & 1 & 0 & 1 & 1 \\
Total & 25 & 28 & 25 & 38 & 34 \\
\hline
\end{tabular}




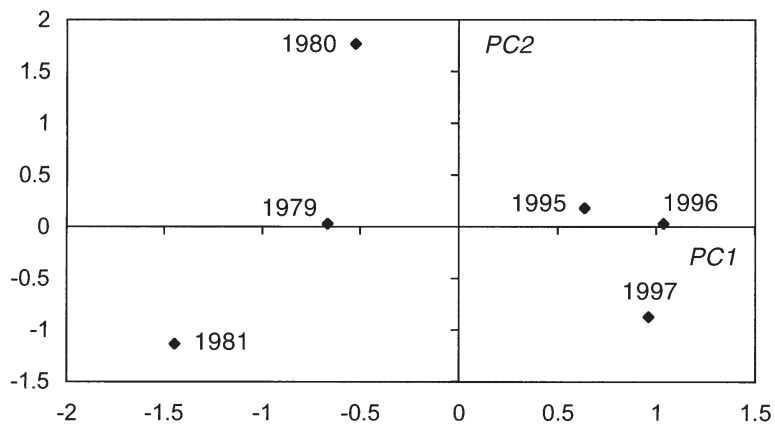

Fig. 5. Ordination diagram of the first 2 axes of the principal components analysis performed on species abundance data

Table 7. Factor loadings of the principal components analysis associated with each species, ${ }^{*}$ loadings higher than 0.7

\begin{tabular}{|lcc|}
\hline Species & PC1 & PC2 \\
\hline A. anguilla & 0.12 & $0.91^{*}$ \\
A. regius & $0.79^{*}$ & -0.26 \\
Atherina spp. & -0.39 & $-0.85^{*}$ \\
B. bocagei & $0.93^{*}$ & -0.28 \\
C. mustela & -0.33 & $0.88^{*}$ \\
D. labrax & 0.61 & 0.41 \\
D. bellottii & $0.85^{*}$ & -0.37 \\
D. vulgaris & $0.74^{*}$ & 0.52 \\
E. encrasicolus & 0.49 & $0.75^{*}$ \\
Gobius spp. & $0.95^{*}$ & 0.16 \\
H. didactylus & $0.86^{*}$ & -0.34 \\
L. aurata & -0.28 & 0.84 \\
L. ramada & $0.95^{*}$ & 0.21 \\
P. flesus & -0.50 & 0.69 \\
Pomatoschistus spp. & 0.58 & 0.10 \\
S. pilchardus & -0.10 & -0.25 \\
Solea spp. & 0.60 & $0.744^{*}$ \\
S. aurata & $0.88^{*}$ & -0.21 \\
Syngnathus spp. & -0.54 & 0.08 \\
T. lucerna & -0.23 & 0.64 \\
\hline
\end{tabular}

\section{DISCUSSION}

The assessment of environmental impacts in biological communities is extremely dependent on the analytical tools used (Warwick \& Clarke 1993). Within the methods applied to the Tagus estuary fish community, multivariate techniques (Principal Components Analysis) best reflected species abundance changes, providing a more informative approach.

Several authors have indicated that multivariate analysis, and particularly ordination, is very sensitive for detecting community changes (e.g. Warwick \& Clarke 1991). Besides principal components analysis (e.g. Araujo et al. 1998), other techniques have been used successfully, namely canonical correspondence analysis (e.g. Attayde \& Bozelli 1998) and multidimensional scaling (e.g. Clarke \& Ainsworth 1993, Warwick \& Clarke 1993).

For the other methods used in the analysis of the Tagus fish community, i.e. species ranking methods and community indices, the results were not so consistent. The patterns relative to baseline and recent surveys were not differentiated using ranking methods. Frontier (1985) suggested that the numerical distribution of individuals among species would exhibit a differential response to disturbance. In disturbed areas a numerical dominance of 1 or a small number of species would be expected, while in stable and undisturbed environments a more equable proportion of the dominant species should be observed. The results obtained for the Tagus fish community showed high variability in rank-abundance distributions, even on a short-term basis. As outlined by Beukema (1988) with reference to a similar species ranking method, the high variability characteristic of certain communities induced by natural fluctuations makes the assessment of disturbances due to anthropogenic factors difficult. This could be particularly so for estuarine systems, which are considered to be unpredictable environments.

Community index values could also be misleading. Warwick \& Clarke (1993) commented that diversity assessments do not behave consistently or predictably in response to environmental stress. Increasing levels of disturbance may decrease, maintain or increase diversity (Huston 1979).

Despite the similarities in the structure of the Tagus estuary fish community in the 2 periods considered (baseline and recent surveys), the relative abundance of species has changed.

Among the species that increased their abundance in the recent surveys were Halobatrachus didactylus, Argyrosomus regius and several species of Sparidae, namely Diplodus bellottii and Sparus aurata. The northern limits of the geographic distributions of these species are within the coast of the Iberian Peninsula. Despite the lack of oceanographic data showing a change in climate, these results suggest that species with southern affinities may have increased their abundance due to recent changes in
Table 8. Mean values of surface water temperature $\left({ }^{\circ} \mathrm{C}\right)$ recorded at identical tidal conditions in the periods 1980-1982 and 1995-1996 (Instituto Hidrográfico unpubl. data)

\begin{tabular}{|lcccc|}
\hline & \multicolumn{2}{c}{ March } & \multicolumn{2}{c|}{ November } \\
& $1980-1982$ & $1995-1996$ & $1980-1982$ & $1995-1996$ \\
\hline Sample size & 7 & 7 & 3 & 3 \\
Mean & 14.09 & 15.33 & 15.43 & 16.67 \\
SD & 0.80 & 0.82 & 0.12 & 0.58 \\
\hline
\end{tabular}




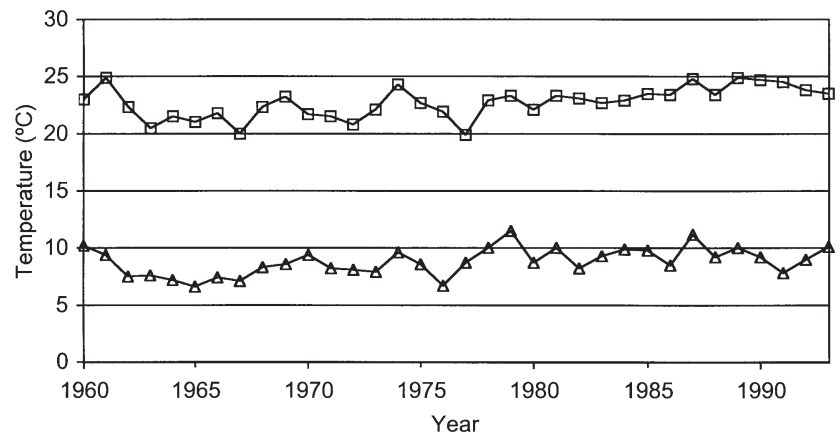

Fig. 6. Maximum and minimum monthly air temperature values recorded in upper Tagus estuary from 1960 until 1993

natural environmental conditions. The decrease in the abundance of Platichthys flesus and Ciliata mustela also corroborates these findings, since the southern limit of their distribution is within the latitudinal range of Portugal. Furthermore, it is reported for $P$. flesus that their eggs are very sensitive to water temperatures higher than $12^{\circ} \mathrm{C}$ (in winter months) which induces high levels of mortality (von Westernhagen 1970). Although the scarcity of environmental data for the Tagus estuary greatly constrains ecological interpretation of the changes recorded, the differences in water temperature between the 2 periods considered suggest that climate was warmer in recent years. The data on air temperature, measured in the upper part of the estuary, also indicate a slight increase in the past few years (maximum temperature: $\mathrm{r}_{\mathrm{s}}=0.59, \mathrm{p}<$ 0.05 ; minimum temperature: $\mathrm{r}_{\mathrm{s}}=0.43, \mathrm{p}$ $<0.05$ ) (Fig. 6).

Other changes reported for the Tagus fish community may be associated with pollution. Costa \& Cabral (1999) suggested that pollution probably induced changes in the nursery function of the Tagus estuary. Anthropogenic pressure also varied from the late 1970s until the present. Several industrial complexes, namely those related to the chemical and shipping industries, have ceased their activity. Although water quality data is lacking, this probably reduced the pollution levels within the estuary. The few time series of data available on water quality show that the concentration of several compounds that are related to pollution, namely phosphates, nitrites and ammonia, present a decreasing trend (phosphates: $\mathrm{r}_{\mathrm{s}}=-0.36$,
Table 9. Mercury concentration $\left(\mathrm{mg} \mathrm{kg}^{-1}\right)$ in several fish species of the Tagus estuary in 1982 and 1998 (Simas 1998, C. Lima unpubl. data)

\begin{tabular}{|lcccc|}
\hline & \multicolumn{2}{c}{1982} & \multicolumn{2}{c|}{1998} \\
Species & Mean & Range & Mean & Range \\
\hline $\begin{array}{l}\text { Dicentrarchus } \\
\text { labrax }\end{array}$ & 0.54 & $0.07-1.69$ & 0.24 & $0.09-0.39$ \\
$\begin{array}{l}\text { Solea } \\
\text { solea } \\
\begin{array}{l}\text { Engraulis } \\
\text { encrasicolus }\end{array}\end{array}$ & 0.07 & $0.03-0.10$ & 0.04 & $0.01-0.07$ \\
$\begin{array}{l}\text { Anguilla } \\
\text { anguilla }\end{array}$ & 0.36 & $0.12-0.80$ & 0.37 & $0.25-0.56$ \\
\hline
\end{tabular}

$\mathrm{p}<0.05$; nitrites: $\mathrm{r}_{\mathrm{s}}=-0.08, \mathrm{p}>0.05$; ammonia: $\mathrm{r}_{\mathrm{s}}=$ $-0.44, \mathrm{p}<0.05$ ) (Figs $7 \& 8$ respectively).

The available information on heavy metal concentration (mainly mercury) in some fish species (Simas 1998, C. Lima unpubl. data), supports a decrease of these pollutants from 1982 to 1998 (Table 9). However, data on other pollutants is not consistent. In recent surveys Bettencourt et al. (1999) reported high levels of TBTs. According to this author the depression of the shipping

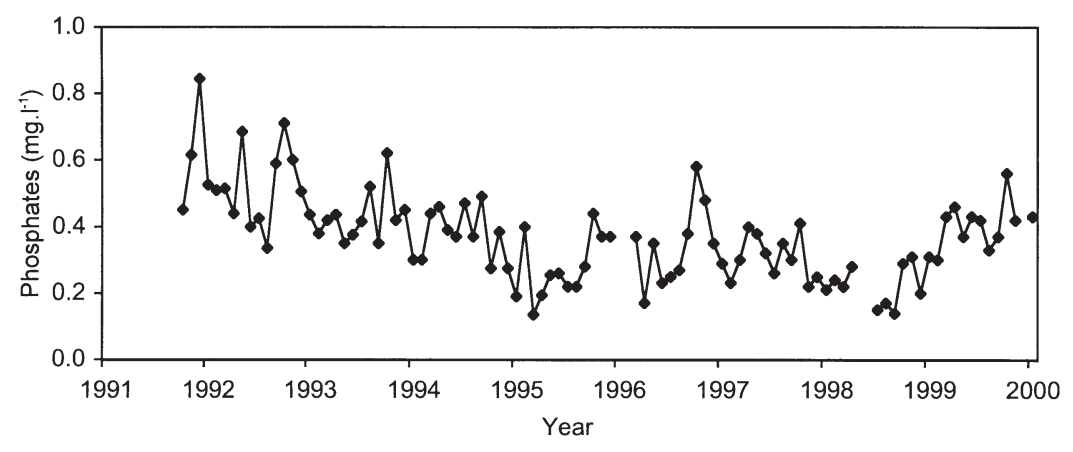

Fig. 7. Phosphates, mean concentration in Tagus river at Valada, $20 \mathrm{~km}$ upstream from estuary, since 1991

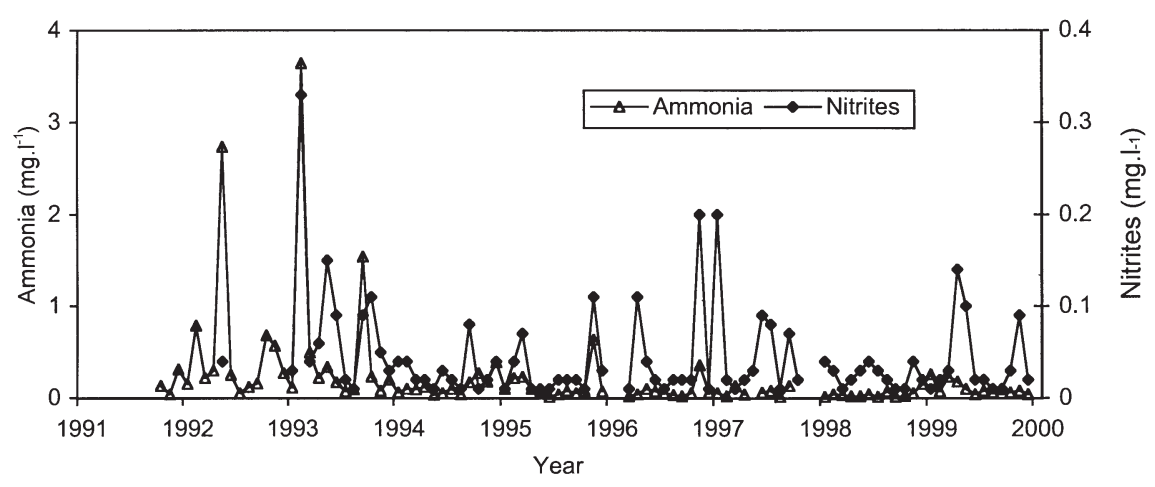

Fig. 8. Nitrites and ammonia, mean concentration in Tagus river at Valada, $20 \mathrm{~km}$ upstream from the estuary, since 1991 
industry in the 1980s was not sufficient to cause a decrease of TBTs in the Tagus estuary.

Sewage discharges into the Tagus estuary have increased in the past years but it is probable that water quality levels have improved since several water treatment plants came into operation.

The decrease in abundance observed for some species, such as Trisopterus luscus and Trigla lucerna, may have been related to environmental quality, since these species are quite common in the adjoining coastal areas of the Tagus estuary (H.N.C. unpubl. data).

One of the main difficulties in relating changes in the fish community of the Tagus estuary to environmental fluctuations was the scarcity of data, especially time series. Long-term changes attract increasing interest from those concerned with ecological and management issues. Therefore effort should be made to develop holistic monitoring programs including several components, namely chemical, hydrographical and biological. Regarding fish communities, beam trawl surveys are a particularly suitable method for estuarine pollution assessment purposes, enabling the identification of long-term trends in species numbers and fish abundance (Pomfret et al. 1988).

\section{LITERATURE CITED}

Araujo FG, Bailey RG, Williams WP (1998) Seasonal and between-year variations of fish populations in the middle Thames estuary: 1980-1989. Fish Manag Ecol 5:1-21

Attayde JL, Bozelli RL (1998) Assessing the indicator properties of zooplankton assemblages to disturbance gradients by canonical correspondence analysis. Can J Fish Aquat Sci 55:1789-1797

Attrill MJ, Depledge MH (1997) Community and population indicators of ecosystem health: targeting links between levels of biological organisation. Aquat Toxicol 38: 183-197

Bettencourt AMM, Andreae MO, Cais Y, Gomes ML, Schebek L, Boas LFV, Rapsomanikis S (1999) Organotin in the Tagus Estuary. Aquat Ecol 33:271-280

Beukema JJ (1988) An evaluation of the ABC-method (abundance/biomass comparison) as applied to macrozoobenthic communities living on tidal flats in the Dutch Wadden Sea. Mar Biol 99:425-433

Cabral HN (1998) Utilização do estuário do Tejo como área de viveiro pelos linguados, Solea solea (L., 1758) e Solea senegalensis Kaup, 1858, e robalo, Dicentrarchus labrax (L., 1758). PhD thesis, Universidade de Lisboa

Clarke KR, Ainsworth M (1993) A method of linking multivariate community structure to environmental variables. Mar Ecol Prog Ser 92:205-219

Clements WH, Kiffney PM (1994) Assessing contaminant effects at higher levels of biological organization. Environ Toxicol Chem 13:357-359

Costa MJ (1986) Les poisson de l'estuaire du Tage. Cybium 10:57-75

Costa MJ, Bruxelas A (1989) The structure of fish communities in the Tagus estuary, Portugal, and its role as a nursery for commercial fish species. Sci Mar 53:561-566

Costa MJ, Cabral HN (1999) Changes in the Tagus nursery function for commercial fish species: perspectives for management. Aquat Ecol 33:287-292

Costa MJ, Elliott M (1991) Fish usage and feeding in two industrialized estuaries - the Tagus, Portugal, and the Forth, Scotland. In: Elliott M, Ducrotoy JP (eds) Estuaries and coasts: spatial and temporal intercomparisons. Olsen \& Olsen, Fredensborg, p 289-297

Costa MJ, Pestana C, Pereira C, Jorge F, Silva G, Salgado JP, Costa J, Gordo LS, Almeida PR (1998) Monitorização ambiental da construção da Ponte Vasco da Gama. Bentos, macroinvertebrados aquáticos e ictiofauna. Technical Report. Centro de Estudos de Monitorização Ambiental, Lisboa

Elliott M, Dewailly F (1995) The structure and components of european estuarine fish assemblages. Neth J Aquat Ecol 29:397-417

Elliott M, Griffiths AH, Taylor CJL (1988) The role of fish studies in estuarine pollution assessment. J Fish Biol 33 (Suppl A):51-61

Fernandes TF, Elliott M, Da Silva MD (1995) The management of european estuaries: a comparison of the features, controls and management framework of the Tagus (Portugal) and the Humber (England). Neth J Aquat Ecol 29: $459-468$

Frontier S (1985) Diversity and structure in aquatic ecosystems. Oceanogr Mar Biol Annu Rev 23:253-312

Haedrich RL (1983) Estuarine fishes. In: Ketchum B (ed) Ecosystems of the world. 26. Estuaries and enclosed seas. Elsevier, Amsterdam, p 183-207

Huston M (1979) A general hypothesis of species diversity. Am Nat 113:81-101

Margalef R (1958) Information theory in ecology. Gen Systematics 3:36-71

McHugh JL (1967) Estuarine nekton. In: Lauff GH (ed) Estuaries. Am Assoc Adv Sci, Publ 83, p 581-620

Paller MH, Reichert MJM, Dean JM (1996) Use of fish communities to assess environmental impacts in South Carolina coastal plain streams. Trans Am Fish Soc 125: $633-644$

Pielou EC (1977) Mathematical ecology. Wiley, New York

Pomfret JR, Turner GS, Phillips S (1988) Beam trawl surveys as a monitoring tool in polluted estuaries in north-east England. J Fish Biol 33(Suppl A):71-77

Shannon CE, Weaver W (1949) The mathematical theory of communication. University Illinois Press, Urbana

Simas MT (1998) Estudo da contaminação por mercúrio em alguns níveis tróficos da Cala do Norte-estuário do Tejo. MSc thesis, Universidade Nova de Lisboa

Statsoft (1993) Statistica for Windows. Statsoft Inc., Tulsa, OK von Westernhagen H (1970) Erbrütung der Eier von Dorsch (Gadus morhua L.), Flunder (Pleuronectes flesus L.) und Scholle (Pleuronectes platessa L.) unter kombinierten Temperatur- und Salzgehaltbedingungen. Helgol Wiss Meeresunters 21:21-102

Warwick RM (1993) Environmental impact studies on marine communities: pragmatical considerations. Aust J Ecol 18: 63-80

Warwick RM, Clarke KR (1991) A comparison of some methods for analysing changes in benthic community structure. J Mar Biol Assoc UK 71:225-244

Warwick RM, Clarke KR (1993) Comparing the severity of disturbance: a meta-analysis of marine macrobenthic community data. Mar Ecol Prog Ser 92:221-231

Whitefield AK (1996) Fishes and the environmental status of South African estuaries. Fish Manag Ecol 3:45-57

Zar J (1996) Biostatistical analysis, 3rd edn. Prentice Hall, Englewood Cliffs 